ZOOLOGIA 29 (5): 405-412, October, 2012

doi: $10.1590 /$ S1984-46702012000500003

\title{
Diet and trophic niche of Lithobates catesbeianus (Amphibia: Anura)
}

\author{
Peterson T. Leivas ${ }^{1,4}$, Fernando W. T. Leivas ${ }^{2} \&$ Maurício O. Moura² \\ 1 Programa de Pós-Graduação em Ecologia e Conservação, Universidade Federal do Paraná. Caixa postal 19020, \\ 81531-980 Curitiba, Paraná, Brazil. \\ 2 Programa de Pós-Graduação em Entomologia, Departamento de Zoologia, Universidade Federal do Paraná. \\ Caixa postal 19020, 81531-980 Curitiba, Paraná, Brazil. \\ ${ }_{4}^{4}$ Corresponding author. E-mail: ptleivas@yahoo.com.br
}

\begin{abstract}
Lithobates catesbeianus (Shaw, 1802) is an invasive anuran introduced in Brazil that is associated with the displacement and the decline of populations of native species worldwide. There is evidence that biological invasions are facilitated by certain attributes of the invading species, for instance niche breath, and that invasive species have a broader ecological niche with respect to native ones. We designed a study to ascertain the temporal, ontogenetic, and sex differences in the niche dynamics of the American bullfrog. We sampled monthly from June 2008 to May 2009 in the state of Paraná, southern Brazil. For each individual, we gathered biometric and stomach content data. We then estimated the niche breath of the juveniles and adults, and compared it between the sexes. A total of 104 females and 77 males were sampled. Lithobates catesbeianus has a generalist diet, preying upon invertebrates and vertebrates. Even though the diet of the studied population varied seasonally, it did not differ between the sexes nor did it respond to biometric variables. Niche breadth was more restricted in the winter than in the autumn. The trophic niche of juveniles and adults did not overlap much when compared with the trophic niche overlap between males and females. Adult males and females had a considerable niche overlap, but females had a broader trophic niche than males in the winter and in the spring. These niche characteristics point to an opportunistic predation strategy that may have facilitated the process of invasion and establishment of this species in the study area.
\end{abstract}

KEY WORDS. Biological invasion; bullfrog; predation.

Biological invasions are recognized worldwide as one of the most complex social and environmental problems because they have negative impacts on the economy and biodiversity of various countries (VILÀ et al. 2010). The negative impacts of invasive species on native ones and which affect local biodiversity can be direct (for instance predation and competition) (AtTieri et al. 2010, SIH et al. 2010) and indirect (such as transmission of pathogens) (SCHLOEgel et al. 2009).

Among the biotic interactions that occur between invasive and native species, predation and competition, which are mediated by resource availability and or are dependent on the density and the behavior of exotic species in the environment (Kupferberg 1997, D'amore \& Mcnicholhas 2009, Sin et al. 2010), modulate the impact of invasive species. However, the main concern with regards to the effects of invasive species on native ones is the risk of population decline, and the displacement of native species (KeNIs et al. 2009), which tend to alter the structure of the entire native community (Desprez-Loustau et al. 2007, KenIs et al. 2009).

The mechanisms that lead to the establishment and development of invasive species are not yet clear (KeANE \& CRAWLEY 2002). There is evidence that they depend on the characteris- tics of 1 ) the environment; 2 ) the native community (presence of predators and availability of resources) (KeANe \& CraWley 2002, Altieri et al. 2010); and 3) the biological attributes of the invading organism (VÁZQUEz 2006).

Among the biological features essential to the process of invasion are the ability of the invading species to undergo rapid evolutionary responses (SAKAI et al. 2001), its reproductive characteristics (such as number of reproductive events, fecundity and parental care) (VÁzQuez 2006) and characteristic of its niche breadth in different dimensions (spatial, temporal and trophic) (CASSEy 2003, VÁzQuez 2006).

The hypothesis that the amplitude of the trophic niche facilitates biological invasions predicts that an alien species with a broad ecological niche (generalists) will be able to explore a wider range of food resources when compared with a species that has a more restricted niche breadth (specialist) (VÁzquEz 2006). A broader niche guarantees a constant input of energy for the basic biological processes (e.g., reproductive events), and consequently has a positive impact on the population dynamics and dispersal of invasive species (KoLAR \& Lodge 2001, VÁzquez 2006).

Lithobates catesbeianus (Shaw, 1802), also known as the American bullfrog, is native to North America. It has been in- 
troduced into over 40 countries due to its economic potential (Ficetola et al. 2007), and is now considered one of the 100 species with greatest invasive potential in the world (Lowe et al. 2004). The American bullfrog has been blamed for the decline of amphibian populations on global and local scales (KATS \& Ferrer 2003). The impact of this frog on native amphibians results from its negative interference in the dynamics of populations and communities through predation/competition (Kupferberg 1997, Pearl et al. 2004, Wu et al. 2005), acoustic interference (Both \& GRANT 2012) and transmission of pathogens (SChloegel et al. 2009).

Lithobates catesbeianus is an opportunistic generalist predator (Toledo et al. 2007). In their native range, individuals of this species consume invertebrates and vertebrates (KaTs \& FERRER 2003). Descriptions of the American bullfrog's diet where it has been introduced in Brazil and the world at large show that $L$. catesbeianus also exerts intense predation on vertebrates (e.g., birds, reptiles, fish, mammals and frogs) (Wu et al. 2005, Boelter \& Cechin 2007, Silva et al. 2009), with possible direct negative effects on native species. Beyond that, microcosms and mesocosms experiments using L. catesbeianus have shown that it has indirect negative affects on other species of frogs, through competition, resulting from niche overlap in space and food (Kiesecker \& Blaustein 1998, Pearl et al. 2004).

Given the background presented above, and considering that there is evidence that $L$. catesbeianus has a negative effect on other species of frogs, which is mediated by predation, and the possible relationship between niche breadth and dominance by $L$. catesbeianus in the system, this study aimed to determine the overall trophic niche breadth of the American Bullfrog in a natural environment.

Specifically, this study was designed to determine: a) whether there is an effect of temporal variation on the dynamics of the niche of the American bullfrog; b) whether ontogenetic differences exist; c) whether there are niche differences between the sexes.

\section{MATERIAL AND METHODS}

The field work was carried out in natural areas disturbed in the cities of Quatro Barras (25 $\left.18^{\prime} 47^{\prime \prime} \mathrm{S}, 48^{\circ} 58^{\prime} 07^{\prime \prime} \mathrm{W}, 936 \mathrm{~m}\right)$,

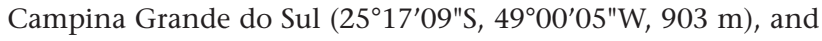
Bocaiúva do Sul $\left(25^{\circ} 14^{\prime} 21^{\prime \prime S}, 49^{\circ} 02^{\prime} 10^{\prime \prime} \mathrm{W}, 980 \mathrm{~m}\right)$, state of Paraná, Brazil. The regional vegetation is Mixed Ombrophilous Mountainous Forest (Araucaria Forest) (IBGE 1992) and the temperate is subtropical type Cfb according to Koppen's classification.

We obtained specimens of L catesbeianus through monthly samples, between June, 2008 and May, 2009 using the active search method (Crump et al. 1994) at night (one night per month in each collection area). After collecting the specimens, we euthanized them in situ with chemical anesthetic according to established protocols (Conselho Federal de Medicina Veterinária, resolution 714). The specimens were cap- tured under license number 10277-1/IBAMA, and voucher specimens for each locality were deposited at the Museu de História Natural do Capão da Imbuia, Curitiba, Paraná, Brazil (MHNCI).

We determined the sex and ontogenetic stage of each specimen and the following biometric variables: snout-vent length (SVL), body mass (BM) and mouth width (MW). Based on these data, we determined the seasonal sex ratio of the population and tested the departure from equality using the chisquare $\left(\chi^{2}\right)$ test with Yates' correction (CALLEgari-JACQUes 2006). To determine the existence of sexual dimorphism in the adults (SVL variables and BM) we used the Student's t test with Welsh's correction (RuxTon 2006).

A ventral incision was performed on each specimen. The stomach and first portion of the intestine of each individual were removed and their contents examined (SCHOENER 1989). We measured the mass (SM), length (SL) and width (SW) of each stomach and estimated its volume (SV) by approximating the shape of the stomach with an ellipsoid, according to the formulae $S V=4 / 3(\mathrm{SL} / 2)(\mathrm{SW} / 2)^{2}$ (Magnusson et al. 2003). All mass measurements were performed using a precision balance $(0.001 \mathrm{~g})$ and length was measured with a digital caliper $(\mathrm{mm})$.

We then quantified and identified the content of each stomach. The volume of prey items was estimated by the method of water column displacement (MAGNUSSON et al. 2003). In order to describe the diet of the population, we used eight major taxonomic prey groups, comprising vertebrates and invertebrates (Annelida, Arachnida, Crustacea, Insecta, Mollusca, Myriapoda, Osteichthyes, and Anura; Tab. I). There were also fragments of feathers, plants and rocks, which were regarded as accidental ingestions, and did not include in the analyses (Tab. I).

We tested the existence of a relationship between the biometric variables (SVL, BM, MW, SM, and SV) and the abundance and richness of food items ingested by males and females through a linear regression (CALLEGARI-JACQUES 2006). In order to test whether body size (SVL) was related to prey volume, we performed a linear regression between these variables. In these cases the biometric variables and the abundance, richness and volume of prey items were logarithmized to meet the assumptions of the parametric tests (CALLEGARI-JACQUES 2006).

In order to determine the contribution of the various food items (taxons) to the diet of the population, we determined the percentage of occurrence (PO) of each item. We also calculated the frequencies of those items separately for juveniles and adults and, within each of those groups, for males and females separately, and for each season. We considered young females with SVL less than $84.5 \mathrm{~mm}$ (LeIvas et al. 2012). Using contingency tables on the PO of food items, we tested the existence of statistical differences in the diet of males and females (CAllegari-Jacques 2006).

Contingency tables were also used to ascertain whether there was a difference in the PO of vertebrates (frogs and fish) in the diet of L. catesbeianus between seasons, and whether there was a difference in the PO of pre and post metamorphic 
Table I. Prey items found in the diet of L. catesbeianus in the municipalities of Campina Grande do Sul, Quatro Barras and Bocaiúva do Sul, State of Paraná, Brazil. Group corresponds to large groups in the diet; Order/Class and Family/Species corresponds to a more refined identification of the items within each group; (NE) number of stomachs in which each item occurred; (POG) percentage of occurrence of the large groups in the diet; (POE) percentage of occurrence of classes or orders in each larger group. Imature insects: (Na) aquatic (naiads), (Nt) terrestrial (nymphs), (Pu) pulpe, (L) larve.

\begin{tabular}{|c|c|c|c|c|c|}
\hline Group & Order/Class & Family/Species & NE & POG (\%) & POE (\%) \\
\hline \multirow[t]{3}{*}{ Annelida } & & & 11 & 4.60 & \\
\hline & Hirudinea & & 2 & & 18.18 \\
\hline & Oligochaeta & & 9 & & 81.82 \\
\hline \multirow[t]{2}{*}{ Arachnida } & & & 45 & 18.80 & \\
\hline & Araneae & & & & \\
\hline \multirow[t]{3}{*}{ Crustacea } & & & 9 & 3.80 & \\
\hline & Decapoda & & 5 & & 55.56 \\
\hline & Isopoda & & 4 & & 44.44 \\
\hline \multirow[t]{13}{*}{ Insecta } & & & 131 & 54.80 & \\
\hline & Non-identified & & $62(1 \mathrm{Na} / 2 \mathrm{Pu} / 3 \mathrm{~L})$ & & 24.49 \\
\hline & Blattodea & & 5 & & 1.98 \\
\hline & Coleoptera & $\begin{array}{l}\text { Scarabaeidae, Hydrophilidae, Staphylinidae, } \\
\text { Curculionidae, Passalidae, Chrysomelidae, Elateridae }\end{array}$ & $41(7 \mathrm{~L})$ & & 16.21 \\
\hline & Diptera & & 6 & & 2.37 \\
\hline & Hemiptera & Belostomatidae, Membracidae & 30 & & 11.86 \\
\hline & Hymenoptera & Apidae: Apis mellifera & 48 & & 18.97 \\
\hline & & Formicidae & & & \\
\hline & Isoptera & & 3 & & 1.19 \\
\hline & Lepidoptera & & 15 (10L) & & 5.93 \\
\hline & Phasmida & & $3(1 \mathrm{Nt})$ & & 1.19 \\
\hline & Odonata & & $24(1 \mathrm{Na})$ & & 9.49 \\
\hline & Orthoptera & Gryllotalpidae, Gryllidae, Proscopiidae & 16 & & 6.32 \\
\hline Mollusca & Gastropoda & & 1 & 0.40 & \\
\hline Myriapoda & Diplopoda & & 9 & 3.80 & \\
\hline \multirow[t]{7}{*}{ Anura } & & & 27 & 11.30 & \\
\hline & Tadpole & Lithobates catesbeianus & 19 & & 57.57 \\
\hline & Post-metamorphic & & 14 & & 42.42 \\
\hline & & Non-identified & & & \\
\hline & & Rhinella abei & & & \\
\hline & & Physalaemus cuvieri & & & \\
\hline & & Hypsiboas bichoffi & & & \\
\hline Osteichthyes & & & 6 & 2.50 & \\
\hline
\end{tabular}

anurans in the diet of the adults. We also tested whether there was a relationship between the environmental variables and the PO of vertebrates in the diet of adult males and females of L. catesbeianus using the Spearman's correlation (CALlegarIJACQUES 2006). We calculated the amplitude of the ecological niche for adults of each sex separately. The niche breadth of these two groups was also calculated for each month and season. In both analyzes we used the standardized index of Shannon-Wiener (KREBS 1999). Using the monthly niche breadth data for each sex and for the population, we tested the relationship between environmental variables (precipitation and mean monthly temperature) and the niche breadth using the Spearman's correlation (CALLEGARI-JACQUES 2006).

We estimated the food niche overlap between males and females of $L$. catesbeianus using the standardized index of PIANKA (1973). This index varies between 0 (no overlap) and 1 (complete overlap) (KreBs 1999). The niche overlap between sexes was also calculated for each season. 
The t-test, contingency tables, linear regression and Spearman's correlation were performed using the program $\mathrm{R}$ (R Development Core Team 2009). Analyzes used to quantify the amplitude of the ecological niche of the species were carried out in the program PAST (HAMmER et al. 2001) and the overlap in food niche was performed using the EcoSim (Gotelli \& ENTSMINGER 2001). All statistical tests were performed with a significance level of 0.05 (CAllegari-Jacques 2006).

\section{RESULTS}

We analyzed a total of 181 samples L. catesbeianus, of which 104 were females and 77 were males. Of the total specimens collected, 173 were adults and eight were young females. The SVL of females ranged between 60.0 and $162.0 \mathrm{~mm}$ and the BM ranged between 20.99 and $508.30 \mathrm{~g}$. In males, the SVL varied between 76.0 and $156.0 \mathrm{~mm}$ and the varied BM between 38.48 and $391.50 \mathrm{~g}$. There was no sexual dimorphism in the SVL of adults (Welsh's t-test $=0.41, \mathrm{df}=171, \mathrm{p}=0.52$, mean $\pm 1 \mathrm{SD}$ : Males $-\mathrm{SVL}=119.1 \pm 42.7 \mathrm{~mm}$ and Females $-\mathrm{SVL}=117.0 \pm 46.4$ $\mathrm{mm}$ ) and the BM (Welsh's t-test $=0.04, \mathrm{df}=171$ and $\mathrm{p}=0.83$, mean \pm 1 SD: Males $-\mathrm{BM}=195.23 \pm 20.16 \mathrm{~g}$ females: $\mathrm{BM}=22.49$ $\pm 192.22 \mathrm{~g}$ ) of the specimens collected.

Spring was the season with a greatest abundance of individuals $(n=59)$, followed by winter $(n=44)$, summer $(n=43)$ and fall $(\mathrm{n}=35)$. The seasonal sex ratio of the total sample showed a significant difference only in the summer $\left(\chi^{2}=3.93\right.$, $\mathrm{df}=1, \mathrm{p}<0.05$ ) when 15 males and 28 females were collected.

Population's diet. Among the stomachs examined, $12.71 \%(\mathrm{n}=23)$ were empty and $87.29 \%(\mathrm{n}=158)$ contained 1 78 items (mean $7.81 \pm 1.56$ ). The richness of prey items was not correlated with the biometric variables analyzed. However, the abundance of prey items was correlated with the SVL $(\rho=-0.145$, $p=0.050)$ and the BM $(\rho=-0.165, p=0.025)$, but not with the other variables. The size of the specimens analyzed (SVL) also was unrelated with the volume of prey in the population of $L$. catesbeianus $\left(\mathrm{r}^{2}=0.0005, \mathrm{~F}=0.097, \mathrm{df}=180, \mathrm{p}=0.75\right)$.

Invertebrates were the most abundant items in the diet of the American Bullfrog (Tab. I), representing $86.20 \%(n=206)$ of the food items encountered by us. The following groups were identified: Arachnida, Mollusca, Myriapoda, Annelida, Crustacea and Insecta, the most abundant group, including ten orders found in the stomach contents (Tab. I). Vertebrates were represented by anurans in different ontogenetic stages and fish juveniles accounted for about $13.80 \%(n=33)$ of the prey items (Tab. I). We considered as accidentally ingested items, plants ( $\mathrm{n}=85$, encountered in $30 \%$ of the samples), rocks ( $\mathrm{n}=$ $13,4.5 \%)$ and feathers $(\mathrm{n}=1,0.4 \%)$.

Diet of juveniles and adults. The diet of young American Bullfrogs consisted predominantly of invertebrates $(\mathrm{PO}=$ $88.9 \%, \mathrm{n}=7)$, being represented by Insecta ( $\mathrm{PO}=66.7 \%, \mathrm{n}=$ $6)$ and Arachnida ( $\mathrm{PO}=22.2 \%, \mathrm{n}=2)$. The vertebrates found in the diet belong only to Osteichthyes $(\mathrm{PO}=11.1 \%, \mathrm{n}=1)$.
The diet of adult bullfrogs consisted of items and their percentages as described in the general diet (Tab. I), with the exception of the items consumed by the juveniles. The diet of adult males and females did not differ in the absolute frequency of occurrence of prey items $\left(\chi^{2}=6.97 ; \mathrm{df}=7, \mathrm{p}>0.5\right)$, and all items were equally consumed by both sexes, except for Shellfish, which were not preyed upon by females.

The PO of vertebrates in the diet of females of $L$. catesbeianus was positively correlated with precipitation ( $\rho=0.159, p=0.620)$ and temperature $(\rho=0.307, p=0.330)$. The PO of vertebrates in the diet of males was positively correlated with the temperature $(\rho=0.262, p=0.410)$. However, the correlation with monthly precipitation was high and significant $(\rho=0.640, p=0.024)$.

Seasonal diet. Invertebrates and vertebrates were preyed upon in all seasons. Among the invertebrates, only Mollusks were preyed upon only in the summer, and Annelids were preyed more intensively in the fall. The other groups had similar rates of predation among seasons (Fig. 1).

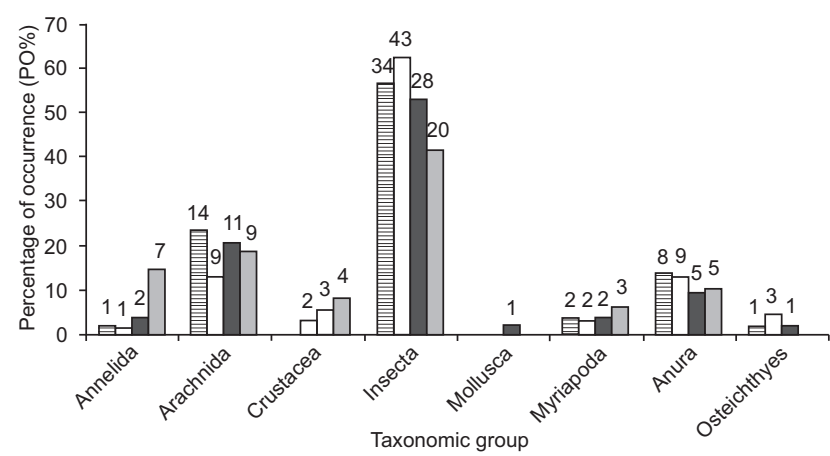

Figure 1. Percentage of occurrence and number of items (above the bars) of each taxonomic group between the seasons, present in the diet of adult Lithobates catesbeianus. Winter (black with white), spring (white), summer (black), and fall (grey).

Seasonally, vertebrates were consumed in greater numbers during the spring, followed by the winter, summer and fall months (Fig. 1). Fish were more intensely consumed in the spring but were not predated during the fall, and in winter and summer fish predation was low. The PO of fish in the diet did not differ significantly among the seasons $\left(\chi^{2}=3.8, \mathrm{df}=3, \mathrm{p}>0.5\right)$ (Fig. 1$)$.

Anurans in different ontogenetic stages were predated upon in all seasons, but were a more frequent diet item in the spring, followed by winter, summer and fall (Fig. 1). However, the PO was higher in winter than in spring and highest in the fall than in the summer (Fig. 1). The difference in predation was not significant between seasons $\left(\chi^{2}=1.88, \mathrm{df}=3, \mathrm{p}=0.25\right)$.

Tadpoles were also present in the diet of $L$. catesbeianus in winter and summer seasons ( $\mathrm{PO}=50, \mathrm{n}=4$ per station), but more frequently in the spring and fall $(\mathrm{PO}=58, \mathrm{n}=7$ and $\mathrm{PO}=$ 
$80, \mathrm{n}=4$ respectively). The occurrence of post-metamorphic individuals in the diet was higher in winter and summer $(\mathrm{PO}=$ $50, \mathrm{n}=4$ and $\mathrm{PO}=50, \mathrm{n}=4$ respectively), followed by the spring and fall ( $\mathrm{PO}=42, \mathrm{n}=5$ and $\mathrm{PO}=20, \mathrm{n}=1$, respectively).

Trophic niche population size and food niche overlap between the sexes. The estimated trophic niche breadth of the L. catesbeianus population was 0.43 . Niche breadth is positively correlated with temperature $(\rho=0.408, p=0.137)$. However, niche breadth is negatively correlated with precipitation $(\rho=-0.190, p=0.009)$. The winter was the season with a smaller range of ecological niches and in the fall the niche breadth of the bullfrogs was greater (Fig. 2).

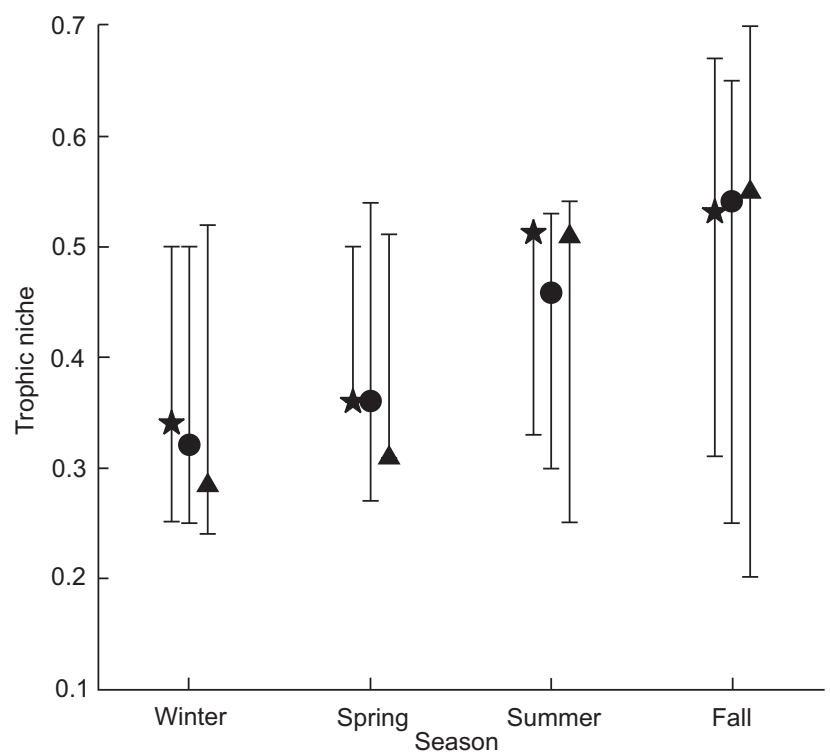

Figure 2. Temporal variation in the amplitude of the trophic niche (Shannon-Weiner) and confidence intervals for all adults of Lithobates catesbeianus (circles), females (star) and males (triangle) between July 2008 and May 2009.

Adult males and females have similar niche breadth: Males 0.42 (mean) and females 0.43 (mean). For both the niche breadth had a positive correlation with temperature $(\rho=0.622$, $\mathrm{p}=0.033 / \rho=0.251, \mathrm{p}=0.423$, females and males respectively) and no correlation with precipitation $(\rho=0.125$, $\mathrm{p}=0.691 / \rho=0.055, \mathrm{p}=0.860$ respectively).

Seasonally, there were no significant differences in the niche breadth of both sexes, since the confidence intervals overlapped. Males and females had the broadest niche breadth in the fall and the narrowest in the winter (Fig. 2). The food niche overlap between adult males and females was considerable (0.99). Seasonally, the food niche of males and females overlapped more in the winter (0.99) and in the summer (0.98), and less in spring (0.94) and fall (0.94) months, though always significantly.

\section{DISCUSSION}

Among the biological factors implicated in biological invasions, the amplitude of the trophic niche can act as a facilitator. Species with broader niches have more resources available to them than species with narrower niches (VÁzQuez 2006). In this context, our results indicate that L. catesbeianus has a generalist diet and a broad trophic niche. Both may derive from an opportunistic predation strategy (Toledo et al. 2007), since they occur both where the species is native and in places where it is invasive (Hirai 2004, Silva et al. 2009).

A similar diet between the sexes had been recorded for the American Bullfrog elsewhere where the species is also invasive (WANG et al. 2007). This may have to do with the relationship between the body size of the predator and that of the prey, and with similarities in the spatial use of the habitat or in the metabolic requirements on the feeding activity of both sexes (Bull 2003, WANG et al. 2007). The differences in diet between juveniles and adults are also likely to be associated with these factors (Wu et al. 2005).

Considering only the relationship between the size of the bodies of predator and prey, the absence of sexual dimorphism (SVL) between the sexes of L catesbeianus may be responsible for their similar diets. Our results indicate that males and females may have the same ability to ingest prey, which decreases the chances of variation in the diet between the sexes (Wu et al. 2005, WANG et al. 2007). However, our results showed no relationship between the SVL and the volume of prey consumed. Thus, if there was sexual dimorphism in the population examined (KaEFER et al. 2007), differences in diet as a result of sexual dimorphism would have been expected (LAmb 1984, Bull 2003).

Besides the size, differences in the diet between the sexes may be considered products of the spatial differences in the use of the habitat (WERnER et al. 1995). The homogeneity of the diet of the population under study may indicate that males and females of L. catesbeianus do not occupy different habitats and/or that the distribution of prey items is homogeneous in the area. We have not tested these hypotheses in this work.

The basal metabolic rate of males and females can directly influence their consumption of prey, thereby determining whether the diet of both sexes is similar or not. When it is similar, it may indicate that both sexes have the same metabolic needs, except in reproductive periods, when one would expect a change in the richness and abundance of food items with respect to other seasons (LAmb 1984, Bull 2003). This hypothesis is strengthened by the observation that the niche of males in all seasons was broader than that of females, except in the winter and spring, which marked the beginning of the breeding season of L. catesbeianus in the location of our study (LeIvas et al. 2012). Thus, during the late winter and the spring, females probably consume more food than in other seasons, in order to meet the metabolic requirements of reproduction. 
The difference in the diet of juveniles and adults can also be related to the size of the body (relative size of predator-prey). Thus, juveniles have greater restrictions on the kinds of prey they consume (particularly with respect to the body mass of the item) (Wu et al. 2005) because predation is limited by the size of the prey. Therefore, considering the differences in body mass among prey items (vertebrates and invertebrates), adults tend to prey on larger organisms (vertebrates). This accounts for a difference in the breath of the niche of adults and juveniles of $L$. catesbeianus.

The breadth of the niche and diet of $L$. catesbeianus is directly influenced by climatic conditions. Anurans increase their activity levels in response to rising temperatures and precipitation (e.g., foraging and feeding) (Duellman \& Trueb 1994). Therefore these factors act together, causing an increase or decrease in the activity of the species (foraging), which lead to increased use of resources (Ryan 1980), extending or restricting the breadth of the niche (VÁzquez 2006).

The trophic niche of L. catesbeianus was broader in the fall and narrower in the winter. This may be also linked to low activity levels of prey items such as insects and frogs in the wintertime (Duellman \& Trueb 1994). In the fall, individuals eat more to store energy reserves to survive the winter, marked by low temperatures and reduced precipitation (DUELLMAN \& TRUEB 1994).

In the present study, L. catesbeianus individuals ate invertebrates and vertebrates, as described in other studies (HIRAI 2004, Boelter \& CeCHin 2007). Among the invertebrates, insects where the most frequently found, and among vertebrates, frogs and fish, consistent with other reports from where the species has been introduced in North America and Brazil (Boelter \& CEсHIN 2007). However, these results differ from the diet of the species in Japan, where only adults of the species preyed on invertebrates (many crustaceans), and vertebrates (fish) were found only in the stomachs of juveniles (HIRAI 2004). It is likely that differences in dietary patterns between these sites are due to environmental conditions and the availability of prey in the environment, since these data refer to the population in these islands.

The fact that the only vertebrates in the diet of the species are frogs and fish is consistent with data from other places where L. catesbeianus is invasive (Hirai 2004, Boelter \& Cechin 2007, SiLva et al. 2009) but contrasts with previous records, which indicate that the species, in its native range, predates on birds, salamanders, mammals and reptiles (CARPENTER et al. 2002, Wu et al. 2005). Cannibalism was recorded for the American Bullfrog in previous studies (BARAsso et al. 2009). However, there is no evidence that the animals recognize the activity as cannibalistic, and this activity is most likely the product of the foraging behavior of the species (Duellman \& Trueb 1994, Toledo et al. 2007). Seasonally, greater numbers of cannibalistic records were obtained in the spring and fall; with the highest rates of tadpoles in the study area in the beginning (spring) and end (fall) of the breeding season (Leivas et al. 2012).
The predation of native species of amphibians, as described in this study, has been reported in various places where L. catesbeianus has been introduced worldwide (WERNER et al. 1995, WANG et al. 2007, BARRASSo et al. 2009), and in the states of Rio Grande do Sul (Boelter \& CeChin 2007) and Minas Gerais, Brazil (SiLve et al. 2009). The records of predation on Rhinella abei (Baldissera-Jr, Caramaschi \& Haddad, 2004) in this study, as well as of $R$. pombali (Baldissera-Jr, Caramaschi \& Haddad, 2004) in Minas Gerais (SILVA et al. 2009), are unusual, probably due to the presence of defense mechanisms (e.g., paratoid gland) (Aнога et al. 2006) in these frogs. These defense mechanisms, however, appear to be ineffective against the predatory activities of L. catesbeianus.

The diet and predatory activity of L catesbeianus reported in this study may be directly influenced by predation, and indirectly by competition via the trophic structure of the local community (see $\mathrm{S}_{\mathrm{IH}}$ et al. 2010). The indirect effect may have to do with trophic competition with native species such as Leptodactylus latrans (Steffen, 1815) (BARRAsso et al. 2009) since the diet and trophic niche breadth of L. catesbeianus includes several items present in the diet of local frogs. From this analysis, the broad trophic niche of $L$. catesbeianus may have been an important feature and one of the mechanisms that have facilitated the process of invasion and establishment of this species in the study location, as previously hypothesized (Vázquez 2006, MacDougall et al. 2009, Sin et al. 2010).

Also, the anthropogenic environments (or in the recovery phase) occupied by L. catesbeianus in the community studied may have facilitated the invasion by the species, because of their simple ecological structure (SHEA \& CHESSON 2002, MARvier et al. 2004). To this, we must add the environmental and biological characteristics of L. catesbeianus. The American Bullfrog occupies open lentic environments (W ANg et al. 2007, D'AMORE $\&$ MCNicholHas 2009) and has rapid evolutionary responses with regards to feeding and reproductive strategies (LeIvas et al. 2012). Additionally, the fact that the founders of the population were genetically pre-selected (they came from breeders) and had gone through an acclimatization period to the local weather conditions in the nurseries, may have positively contributed to the invasion process.

\section{ACKNOWLEDGMENTS}

We thank Carlos E. Conte, Fernando Passos, and Luis F. Fávaro for review the manuscript and José P. Pombal Jr for valuable comments on the manuscript. This research was partially supported by grants from the Conselho de Desenvolvimento Cientifico e Tecnologico (CNPq process 475461/2007 and $312357 / 2006$ ) to Mauricio O. Moura. Peterson T. Leivas received a masters stipend from the Coordenacão de Aperfeiçoamento de Pessoal de Nível Superior - CAPES. Fernando W.T. Leivas received a masters stipend from the CNPq. 


\section{LITERATURE CITED}

Ahola, M.; M. Nordstro; E. Korpima; P.B. Banks \& N. Laanetu. 2006. Alien mink predation induces prolonged declines in archipelago amphibians. Proceedings of the Royal Society 273: 1261-1265.

Altieri, A.H.; B.K.V. Wesenbeeck; M.D. Bertness \& B.R. Silliman. 2010. Facilitation cascade drives positive relationship between native biodiversity and invasion success. Ecology 91 (5): 1269-1275.

Barrasso, D.A.; R. Cajade; S.J. Nenda; G. Baloriani \& R. Herrera. 2009. Introduction of the American Bullfrog Lithobates catesbeianus (Anura: Ranidae) in Natural and Modified Environments: An Increasing Conservation Problem in Argentina. South American Journal of Herpetology 4: 68-75.

Boelter, R.A. \& S.Z. Cechin. 2007. Impact of the bullfrog diet (Lithobates catesbeianus Anura, Ranidae) on native fauna: case study from the region of Agudo, RS,Brazil. Natureza \& Conservação 5 (2): 115-123.

Both, C. \& T. Grant. 2012. Biological invasions and the acoustic niche: the effect of bullfrog calls on acoustic signals of Whitebanded tree frogs. Biology Letters 8 (5): 714-716. doi:10. 1098/rsbl.2012.0412.

BuLL, E.L. 2003. Diet and prey availability of Columbia spotted frogs in northeastern Oregon. Northwest Science 77: 349-356.

Callegari-Jacques, S.M. 2006. Bioestatística: princípio e aplicações. Porto Alegre, 264p.

Carpenter, N.M.; M.L. Casazza \& G.D. Wylie. 2002. Rana catesbeianus (bullfrog). Diet. Herpetology Review 33: 130.

Cassey, P. 2003. A comparative analysis of the relative success of introduced land birds on islands. Evolution Ecololgy Research 5: 1011-1021.

Crump, M.L. \& N.J. Scott Jr. 1994. Standart techniques for inventory and monitoring - Visual encounters surveys, p. 84-91. In: W.R. Heyer; M.A. Donnelly; R.W. Mcdiarmid; L.C. Hayek \& M.S. Foster (Eds). Measuring and Monitoring Biological Diversity - standard methods for amphibians. Washington, D.C., Smithsonian Insitution Press, XIX+364p.

D'Amore, A.E. \& K. Mcnicholhas. 2009. Invasive species shifts ontogenetic resource partitioning and microhabitat use of a threatened native amphibian. Aquatic Conservation: Marine and Freshwater Ecosystems 19: 534-541.

Desprez-Loustau, M.L.; C. Robin \& M. Buée. 2007. The fungal dimension of biological invasions. Trends in Ecology and Evolution 22: 472-80.

Duellman, W.E. \& L. Trueb. 1994. Biology of Amphibians. New York, McGraw-Hill, 670p.

Ficetola, G.F.; W. Thuiller \& C. Miaud. 2007. Prediction and validation of the potential global distribution of a problematic alien invasive species-the American bullfrog. Diversity and Distribution 13: 476-485.

Gotelli, N.J. \& G.L. Entsminger. 2001. Program EcoSim: Null models software for ecology. Acquired Intelligence Inc. \&
Kesey-Bear, version 7.0, Available on line at: http://homepages.together.net/ gentsmin/ecosim.htm [Accessed: 17/V/ 2012].

Hammer O.; D.A.T. Harper \& P.D. Ryan. 2001. Program PAST: Paleontological Statistic software package for education and data analysis. Paleontologia Electronica 4: 9.

HiraI, T. 2004. Diet composition of introduced bullfrog, Rana catesbeiana, in the Mizorogaike Pond of Kyoto Japan. Ecological Research 19: 375-380.

IBGE. 1992. Manual tecnico da vegetacao brasileira. Rio de Janeiro, Instituto Brasileiro de Geografia e Estatistica, Série Manuais Tecnicos em Geociencias.

Kaefer, I.L.; R.A. Boelter \& S.Z. Cechin. 2007. Reproductive biology of the invasive bullfrog Lithobates catesbeianus in southern Brazil. Finnish Zoological and Botanical Publishing Board 44: 435-444.

Kats, L.B. \& R.P. Ferrer. 2003. Alien predators and amphibian declines: review of two decades of science and the transition to conservation. Diversity Distribuition 9: 99-110.

Keane, R.M. \& M.J. Crawley. 2002. Exotic plant invasions and the enemy release hypothesis. Trends in Ecology and Evolution 17 (2): 167-170.

Kenis, M.; M.A. Auger-Rozenberg; A. Roques. 2009. Ecological effects of invasive alien insects. Biological Invasion 11: 21-45.

Kiesecker, J.M. \& A.R. Blaustein. 1998. Effects of introduced bullfrog and smallmouth bass on microhabitat use, growth, and survival of native red-legged frogs (Rana aurora). Conservation Biology 12: 776-787.

Kolar, C.S. \& D.M. Lodge. 2001. Progress in invasion biology: predicting invaders. Trends Ecology Evoution 16: 199-204.

KREBS, C.J. 1999. Ecological methodology. Menlo Park, Addison Wesley Educational Publishers.

KuPferberG, S.J. 1997. Bullfrog (Rana catesbeiana) Invasion of a California river: the role of competition. Ecology 78: 1736-1751.

Leivas, P.T.; M.O. Moura \& L.F. Fávaro. 2012. The reproductive biology of the invasive Lithobates catesbeianus (Amphibia: Anura). Journal of Herpetology 46 (2): 153-161.

LAMB, T. 1984. The influence of sex and breeding condition on microhabitat selection and diet in the Pig Frog Rana grylio. American Midland Naturalist 111: 311-318.

Lowe, S.J.; M. Browne; S. Boudjelas \& M. De Poorter. 2004. 100 of the World's Worst Invasive Alien Species: A selection from the Global Invasive Species Database. IUCN, SSC and ISSG, Auckland, New Zealand.

MacDougall, A.S.: G.B. Jonathan \& M. Levine. 2009. Plant invasions and the niche. Journal of Ecology 97: 609-615.

Magnusson, W.E.; A.P. Lima; W.A. Silva \& M.C. Araújo. 2003. Use of geometric forms to estimate volume of invertebrates in ecological studies of dietary overlap. Copeia 2003 (1): 13-19.

Marvier, M.; P. Kareiva \& M.G. Neubert. 2004. Habitat destruction, fragmentation, and disturbance promote invasion by habitat generalists in a multispecies metapopulation. Risk Analysis 24: 869-878. 
Pearl, C.A.; M.J. Adams; R.B. Bury \& B. Mccreary. 2004. Asymmetrical effects of introduced Bullfrogs (Rana catesbeiana) on native ranid frogs in Oregon. Copeia 2004 (1): 11-20.

PIANKA, E.R. 1973. The structure of lizards communities. Ecology and Systematics 4: 53-74.

RYAN, M.J. 1980. The reproductive behavior of the bullfrog (Rana catesbeiana). Copeia 1980 (1): 108-114.

R Development Core Team. 2009. Program R: A language and environment for statistical computing. R Foundation for Statistical Computing. Available on line at: http://www.rproject.org [Accessed: 17/V/2012].

Ruxton, G.D. 2006. The unequal variance t-test is an underused alternative to Student's t-test and the Mann-Whitney U test. Behavioral Ecology 4: 688-690.

SAKaI, A.K.; F.W. Allendorf; J.S. Holt; D.M. Lodge; J. Molofsky \& K.A. Wrth. 2001. The population biology of invasive species. Annual Review of Ecology and Systematics 32: 305-332.

Schloegel, L.M.; A.M. Picco; A.M. Kilpatrick; A.J. Davies; A.D. Hyatt $\&$ P. DASZAK. 2009. Magnitude of the US trade in amphibians and presence of Batrachochytrium dendrobatidis and ranavirus infection in imported North American bullfrogs (Rana catesbeiana). Biological Conservation 142: 1420-1426.

Schoener, T.W. 1989. Food webs from the small to the large. Ecology 70: 1559-1589.

SheA, K. \& P.L. Chesson. 2002. Community ecology theory as a framework for biological invasions. Trends in Ecology and Evolution 17: 170-176.

Sih, A.; D.I. Bolnick; B. Luttbeg; J.L. Orrock; S.D. Peacor; L.M. Pintor; E. Preisser; J. Rehage \& J.R. Vonesh. 2010. Predatorprey naivete, antipredator behavior, and the ecology of predator invasions. Oikos 119: 610-621.

Silva, E.T.; E.P. ReIs; R.E. Feio \& O.P.R. Filho. 2009. Diet of the invasive frog Lithobates catesbeianus (Shaw, 1802) (Anura: ranidae) in Viçosa, Estado de Minas Gerais, Brazil. South American Journal of Herpetology 4 (3): 286-294.

Toledo, L.F.; R.R. Silva \& C.F.B. Haddad. 2007. Anurans as prey: an exploratory analysis and size relationships between predators and their prey. Journal of Zoology 271: 170-177.

VÁzQUeZ, D.P. 2006. Exploring the relationship between niche breadth and invasion success, p. 307-322 In: M.W. CADOTTE; S.M. McMahon \& T. Fukami (Eds). Conceptual ecology and invasions biology. Dordrecht, Springer.

Vilà, M.; W. Nentwig; C. Basnou; S. Olenin; P. Pysek; A. Roques; M. Josefsson; D. Roy; P. Genovesi; P.E. Hulme \& DAISIE Partners. 2010. How well do we understand the impacts of alien species on ecosystem services? A pan-European, cross-taxa assessment. Frontiers in Ecology and the Environment 8: 135-144.

Wang, Y.; Z. Guo; C.A. Pearl \& Y. Li. 2007. Body size affects the predatory interactions between introduced American Bullfrogs (Rana catesbeiana) and native anurans in China: an experimental study. Journal of Herpetology 41: 514-520.

Werner, E.E.; G.A. Wellborn \& M.A. McPeek. 1995. Diet composition in post metamorphic bullfrogs and green frogs: implications for interspecific predation and competition. Journal of Herpetology 29: 600-607.

Wu, Z.; Y. LI; Y. WANG \& M.J. Adams. 2005. Diet in introduced bullfrogs (Rana catesbeiana): Predation on and diet overlap with native frogs on Daishan Island, China. Journal of Herpetology 39: 668-674.

Submitted: 21.V.2012; Accepted: 27.VI.2012.

Editorial responsibility: Kleber Del Claro

ZOOLOGIA 29 (5): 405-412, October, 2012 